\title{
J. Maringer's Views \\ on the Development of Stone Age \\ in Inner and Outer Mongolia
}

\author{
Daniil O. Nikulin* \\ Novosibirsk State National Research University \\ 2 Pirogova Str., Novosibirsk, 630090, Russia
}

Received 27.06.2016, received in revised form 27.07.2016, accepted 03.09.2016

This article concerns John Maringer's views on the development of Stone Age in Mongolia. It aims to analyse his works as an important stage of the archaeological study of the Mongolian Stone Age in early 20th century; some feedback and criticism from different authors, both from Russia and from the West, are also discussed. J. Maringer performs the biggest role in the study of the archeological legacy of the Sino-Swedish Expedition led by S. Hedin and the Central-Asian Expedition led by R.C. Andrews. However, he remains relatively unknown in Russian historiography despite his important and somewhat unique role in the archaeological study of Central Asia and, more precisely, the Sino-Swedish Expedition, which by itself deserves more interest from Russian science. Connection between Southern Siberia and Mongolia, as seen by J. Maringer, might be of some interest for Russian archaeology. Some of his other points state absence of any evidence of the shift from Mesolithic to Late Neolithic times and the division of Neolithic period in Inner Mongolia into several sub-categories, namely facies. It is important for the historiography of archaelogy as it is viewed in Russia to include these studies since they were very progressive for their time and gathered a lot of archaeological evidence.

Keywords: Maringer, archaeology, Mongolia, historiography, Neolithic.

DOI: 10.17516/1997-1370-2016-9-10-2460-2464.

Research area: theory and history of culture.

\section{Introduction}

J. Maringer plays the largest role in the study of the archaeological legacy of the SinoSwedish expedition led by S. Hedin and Central Asian expedition led by R.C. Andrews. These two expeditions have found similar and rich material. However, the existing traits allowed J. Maringer to offer a hypothesis that there were differences between the Stone Age cultures in
Inner and Outer Mongolia. The purpose of this article is to analyse J. Maringer's views on the genesis, as well as the similarities and differences of the archaeological cultures of Mongolian Stone Age, as these views are an important stage in the development of the archaeological study of the Stone Age in Mongolia in the early $20^{\text {th }}$ century.

In 1922-1923 members of the American Central Asian expedition led by R.C. Andrews

(C) Siberian Federal University. All rights reserved

* Corresponding author E-mail address: poly@admin.nsu.ru 
found flint tools and pottery in different parts of the Gobi desert. These findings were the first to show that Inner Mongolia was inhabited in the Stone Age. Subsequent research in Outer Mongolia led the expedition to the discovery of about 180 Stone Age monuments, in which about 200 thousand artifacts were collected. Of these, about 50 thousand samples were selected for further study. A similar campaign was later carried out in Inner Mongolia by the Sino-Swedish Expedition (1927-1935) under the leadership of S. Hedin. The total number of artifacts and pottery fragments brought to Stockholm, according to J. Maringer, is no less than 50 thousand.

\section{Palaeolithic and Mesolithic}

The collections of Inner Mongolia stone artifacts attributed to the Paleolithic period include side scrapers, Mousterian type choppers and scrapers as well as cutters of Aurignacian type. The majority of the materials can be referred to as flint. Also agate, jasper, and chalcedony were found.

Traces of Mesolithic Shabarakh culture, which was discovered by N. Nelson in Outer Mongolia, were found by J. Maringer in Inner Mongolia in Ikhen-Gung and Gurnai. In IkhenGung he assumed complete absence of ceramics (Maringer, 1963, 78). Several Neolithic pottery fragments found rather indicate a later contact with Neolithic culture or re-occupation of the monument by the Neolithic man. Microlithic tools, axes, and the absence of hand-worked and painted pottery suggest that the territory of habitat of the originally Mesolithic population was penetrated by representatives of Later Neolithic culture of northern China.

J. Maringer also notes some regional differences depending on the topographical conditions. Findings from Gurnai show that the transition from the Mesolithic to the Later Neolithic occurred without abrupt changes in culture. In Beli Miao the number of small arrowheads indicates hunting, while along the rivers and on the coast of Sogho-nor fishing was of more importance and flourished there. With a decrease in the number of large animals at the end of the Ice Age, it is clear that the small and medium-sized animals became more popular as game. In Ukh-tokhoi Neolithic hunters even became craftsmen.

To prove the existence of the Mongolian Mesolithic culture, J. Maringer indicates the findings of the Andrews' expedition in Shabarak Usu in the Central Gobi (Maringer, 1963, 78). Here two cultural levels were found, namely, materials included microlithic cores of conical and cylindrical shape, blades, drills, end-scrapers and characteristic Mesolithic cultural elements-beads made of ostrich eggs. Comparison of materials from Inner Mongolia and Outer Mongolia has revealed some differences. A significantly greater number of beads made of shell shows that Mesolithic people of Outer Mongolia were more numerous. More arrowheads and spears found led J. Maringer to the conclusion that in Outer Mongolia hunting was a more important task.

\section{Neolithic}

The Neolithic culture grew out of the Mesolithic culture, but spread wider (Maringer, 1963, 78). Industry based on microlites included larger forms. Other Neolithic artifacts, i.e. stone axes, knives, arrowheads and spears with simple retouching, grinding stones and pottery, also appeared at the time. Axes from Inner Mongolia show three stages of technical finish: chipped, chipped with slight polish near working edge, fully polished. Among chipped axes some samples show similarities with the early Neolithic period of Northern Europe. However, the Mongolian samples are thinner and seem to be more advanced and recent. However, the assumption that the axes of Northern Europe can 
be considered as prototypes of the Mongolian ones seems weak to J. Maringer, as there were found no axes of intermediate forms in the regions between Europe and Mongolia (Maringer, 1951, 76). For J. Maringer it is more important here that the sharpened blades were already known in the Early Neolithic Russia (Maringer, 1950, 186).

In addition to pottery fragments with woven patterns, fragments with an engraved, carved ornament and clay bands were found, as well as some painted pottery from Northern China.

At the end of the Neolithic period in Inner Mongolia J. Maringer distinguishes four major regional group, whose artifacts correspond to the following four cultural facies: Steppe (specific groups - Khadain Sume, Beli-Miao, and Hongohor-Obo), Alakshan (groups - UkhTokhoi and Abderungtei), Edsen-gol (Sogho-nor and Gurnai), and the Black Gobi. Some of them were not only from the Later Neolithic period, but also of an earlier time. Except for the Black Gobi facies others indicate the penetration of the Northern Chinese culture in the form of painted pottery, axes, findings which often came from the steppes and deserts. Thus, it is important not only to concern the line along the border, but also contacts deeper into Mongolia. Trade was likely to be developed here; there were regular raids from Mongolia to the rich agricultural area of China.

Hunters had bows and arrows with arrowheads made of stone and bone. In bone spearheads there were inserted sharp microlites; carefully retouched flint was used. In addition, the inventory included bone knives with inserted microlites, small blades; rough scrapers and knives were used for the preparation of animals and their skins. Primitive flakes, blades and cutters were used only for cleaning or cutting fish.

But even in the Later Neolithic period in Inner Mongolia there were no agricultural implements such as stone shovels, hoes with handles and weights for digging stick. Mealing stones were used for grinding seeds of wild plants. Besides, mealing stones that were found in the border regions could be objects of trade. J. Maringer suggests that the inhabitants of the Stone Age in Mongolia were nomads engaged in cattle breeding. As for the border area between China and Mongolia, perhaps, agriculture flourished there. However, this does not apply to the most of Mongolia. As for stone axes, or tools reminding them, J. Maringer believes that they were used for cutting wood (Maringer, 1963, 80).

Metal tools are almost completely absent among the evidence of the Stone Age Inner Mongolia. Isolated findings from the Black Gobi to the west of Ugh-tokhoi might be an exception (Maringer, 1951, 74).

\section{Problem of the Mongolian Stone Age Origin}

The origin of the Paleolithic Era in Mongolia is initially not clear. J. Maringer considered Paleolithic Ordos, where there are similar Mousterian-Aurignacian characteristics, the northern Chinese Paleolithic period of Zhoukoudian, Manchuria or Paleolithic culture of southern Siberia. He agreed that samples from Altan Boulaq were very similar to those of the confluence of the Selenga and Chikhoi rivers in Transbaikalia. Among the most important elements of the Isakovo culture are short and thin triangular arrowheads with a concave base and the knives with curved back, spread in Inner Mongolia. Serovo stage, closely associated with Isakovo culture, offers, in addition to the slender triangular arrowheads with concave base, fine broad and curved knives. They are also found in Inner Mongolia, although rarely. J. Maringer concludes that the Mongolian Paleolithic culture came from the Paleolithic cultural region of southern Siberia, and it was the first appearance 
of man in Mongolia (Maringer, 1963, 80). These hunting groups have settled in all Mongolia up to Ordos; Ordos culture was associated with the simultaneous culture of Yenisei-Baikal region.

With regard to the Mesolithic and Neolithic cultures, all types of artifacts and landscape also suggest parallels between the early stage of the Neolithic Era of South Siberia and Inner Mongolia. On the other hand, there is a clear cultural border between Mongolia and the area of the Yellow Earth in the south, where agriculture was practiced.

\section{Conclusion}

Based on the study of Mongolian collections, it became clear for J. Maringer that the Stone Age of Mongolia was largely connected to the neighbour culture of the northwest area. This assumption seems to be more convincing to him than a comparison with a completely different industry of the Stone Age to the south and southeast.

In the historiography his work was viewed in different ways. For example, W. Watson, in a review published in the journal "Man", didn't criticize J. Maringer, but only hoped that the study of the Mongolian Neolithic period would continue and wondered about the origin of the Mongolian nomads (Watson, 1951, 159). A.P. Okladnikov in the article "New data on the ancient history of Inner Mongolia" admits that J. Maringer's attempt to create cultural stratigraphic scheme failed (Okladnikov, 1951, 169) and that viewing of the Mongolian Neolithic period in the context of European material is wrong. He also noted there that J. Maringer's information on the works of Soviet scholars on the Yenisei, Altai and Angara was obsolete (Okladnikov, 1951, 173). S.A. Gladyshev and A.V. Tabarev in a relatively recent article in the "NSU Vestnik" support J.Maringer on matters of production technology of the tools (Gladyshev, Tabarev, 2011, 31).

Thus, based on the study of three works by J. Maringer (Maringer, 1950, 1951; 1963), we can draw the following conclusions:

- Findings of the Sino-Swedish and the Central Asian expedition discovered the Stone Age archeological artifacts in Mongolia;

- Transition from the Mesolithic to the Late Neolithic period could not be traced;

- At the end of the Neolithic period in Inner Mongolia it was possible to distinguish four major territorial groups - facies: Steppe, Alakshan, Edsen-gol, and Gurnai (Maringer, 1950, 184);

- Representatives of the Stone Age in Mongolia were nomads;

- Mongolian Paleolithic culture came from the Paleolithic cultural region of southern Siberia; Mesolithic and Neolithic cultures are also linked with the north.

\section{References}

Gladyshev, S.A., Tabarev A. V. (2011). Sino-Swedish Expedition of Sven Hedin, In NSU Vestnik. Series: History, Philology, 10 (7), 27-32.

Maringer, J. (1950). Contribution to the Prehistory of Mongolia: a Study of the Prehistoric Collections from Inner Mongolia. Stockholm, Thule, $216 \mathrm{p}$.

Maringer, J. (1951). Some Refined Tool-Shapes of the Mongolian Stone Age, In Artibus Asiae, 14 (1/2), 72-76.

Maringer, J. (1963). Mongolia before the Mongols, In Arctic Anthropology, 1 (2), 75-85.

Okladnikov, A. P. (1951). New Data on the Ancient History of Inner Mongolia, In Journal of Ancient History, 4, 162-174.

Watson, W. (1951). Contribution to the Prehistory of Mongolia by John Maringer, In Man, 51, 158-159. 


\title{
Взгляды Дж. Марингера \\ на развитие каменного века \\ во Внешней и Внутренней Монголии
}

\author{
Д.О. Никулин \\ Новосибирский государственный \\ национальный исследовательский университет \\ Россия, 630090, Новосибирск, ул. Пирогова, 2
}

Эта статья затрагивает взгляды Дж. Марингера на развитие каменного века в Монголии. Необходимо рассмотреть его работы как важную стадию истории археологического изучения каменного века Монголии в первой трети ХХ в.; также затронуты критика и мнение о Дж. Марингере различных авторов, как российских, так и зарубежных. Дж. Марингеру принадлежит наибольшая роль в изучении археологического наследия Китайско-Шведской экспедииии С. Хедина и Центральноазиатской экспедиции Р. Ч. Эндрюса. Однако он остается относительно неизвестным в отечественной историографии, несмотря на его важную и в чём-то уникальную роль в археологическом изучении Центральной Азии и конкретно Китайско-Шведской экспедиции, самой по себе заслуживающей большего интереса со стороны российской науки. Параллель, проводимая Дж. Марингером между Южной Сибирью и Монголией, также может представлять некий интерес для российской археологии. Некоторые другие положения его точки зрения - отсутствие свидетельств перехода от мезолита вплоть до позднего неолита и разделение неолита Внутренней Монголии на несколько фаџий. Для отечественной историографии археологии важно учитывать эти исследования, так как они были передовыми в свое время и взаимодействовали с большим количеством археологического материала.

Ключевые слова: Марингер, археология, Монголия, историография, неолит.

Научная специальность: 24.00.01 - теория и история культуры. 